\title{
Studi Kasus: Permasalahan Limbah di Tempat Pemotongan Hewan (TPH) Amessangeng, Kota Sengkang
}

Besse Mahbuba We Tenri Gading ${ }^{1 *}$, Adib Norma Respati ${ }^{2}$, Edi Suryanto ${ }^{3}$

${ }^{1}$ Program Studi Peternakan, Fakultas Peternakan dan Perikanan, Universitas Sulawesi Barat

${ }^{2}$ Program Studi Peternakan, Fakultas Pertanian, Universitas Islam Batik Surakarta

${ }^{3}$ Fakultas Peternakan, Universitas Gadjah Mada

\section{ARTIKEL INFO}

Sejarah artikel

Diterima 03/05/2021

Diterima dalam bentuk revisi 11/05/2021

Diterima dan disetujui 04/06/2021

Tersedia online 22/06/2021

Kata kunci

Limbah

Pencemaran

Tempat pemotongan hewan

\section{ABSTRAK}

Tempat Pemotongan Hewan yang memenuhi persyaratan teknis yang ditetapkan oleh Kementerian Pertanian. Untuk menyediakan daging yang Aman, Sehat, Utuh, dan Halal (ASUH) harus memenuhi persyaratan teknis yang meliputi fisik (bangunan dan peralatan), sumber daya manusia, dan prosedur teknis pelaksanaannya. Penelitian ini dilaksanakan di Tempat Pemotongan Hewan (TPH) Amessangeng yang berlokasi di Kota Sengkang yaitu di Kelurahan Lamaddukelleng, Kecamatan Tempe, Kabupaten Wajo, Sulawesi Selatan. Tujuan penelitian ini adalah untuk mengetahui kondisi penanganan limbah di TPH Amessangeng, terkait langkah penanganan limbah yang telah dilaksanakan untuk mencegah terjadinya pencemaran lingkungan. Metodologi penelitian yang digunakan adalah penelitian deskriptif kualitatif. TPH Amessangeng telah memiliki sarana dan prasarana yang memadai untuk pemotongan hewan, namun berdasarkan hasil pengamatan menunjukkan bahwa kondisi pengolahan limbah belum tersedia. Limbah TPH Amessangeng langsung mengalir ke lahan yang berujung di sungai, belum dilakukan penyaringan telebih dahulu. Jika terjadi terus menerus dan dalam jumlah yang banyak maka dapat berdampak terhadap masyarakat sekitar yang meliputi polusi bau atau pencemaran udara, pencemaran air dan berdampak pada kesehatan. Pembuatan kolam penampungan limbah harus dilakukan dan dilanjutkan dengan pengolahan limbah menggunakan Instalasi Pengolahan Air limbah (IPAL) sebelum limbah dibuang ke sungai sekitar TPH. Hal ini penting dilakukan untuk mencegah terjadinya pencemaran udara, air, tanah dan gangguan kesehatan. 


\section{ABSTRACT}

Slaughterhouses must meet the technical requirements set by the Ministry of Agriculture. To provide Safe, Healthy, Whole, and Halal meat, it must meet technical requirements which covering physical (building and equipment), human resources, and technical procedures for its implementation. This research was conducted at the Amessangeng Slaughterhouse (TPH Amessangeng), located in Sengkang City, Lamaddukelleng Village, Tempe District, Wajo Regency, South Sulawesi. The purpose of this study was to determine the conditions of handling TPH Amessangeng waste, related to the waste handling steps that have been implemented to prevent environmental pollution. The research methodology used is descriptive qualitative research. TPH Amessangeng already has adequate facilities and infrastructure for slaughtering

\section{PENDAHULUAN}

Rumah Potong Hewan (RPH) adalah suatu bangunan atau komplek bangunan dengan desain dan syarat tertentu yang digunakan sebagai tempat memotong hewan bagi konsumsi masyarakat umum. Khasrad et al. (2012) menyatakan Tempat Pemotongan Hewan (TPH) merupakan penyangga bagi RPH dalam penyediaan daging yang aman, sehat, utuh dan halal (ASUH). TPH sebagai penyangga, tetapi persyaratan dan kondisi pemotongan hewan harus sama, supaya daging yang dihasilkan terjamin kualitasnya.

Perbedaan antara RPH dan TPH dapat dikategorikan dalam beberapa tipe. Pertama rata-rata TPH adalah milik swasta, sementara RPH dimiliki oleh pemerintah negeri. Perbedaan yang paling signifikan adalah RPH mempunyai laboratorium bersamaan dengan bangunan RPH, sementara TPH memiliki laboratorium pada animals, but based on observations it shows that the conditions for sewage treatment are not yet available. TPH Amessangeng waste flows directly to the land which ends in a river, no filtering has yet been carried out. If it happens continuously and in large numbers, it can have an impact on the surrounding community which includes odor pollution or air pollution, water pollution, and has an impact on health. The construction of a waste storage pond must be carried out and continued with waste treatment using a Wastewater Treatment Plant before the waste is discharged into the river around the TPH. This is important to do to prevent air pollution, water pollution, soil pollution, and health problems.

kandang atau feedlot. Laboratorium RPH untuk menguji kesehatan ternak dan kesehatan daging yang ingin di distribusikan. Sementara laboratorium milik TPH hanya menguji kesehatan daging saat akan didistribusikan. TPH sendiri dapat digolongkan menjadi 2 yaitu modern dan tradisional (Darsono, 2006).

Lokasi RPH/TPH harus memenuhi persyaratan seperti tidak mencemari lingkungan dan menimbulkan gangguan selain itu harus memiliki akses air bersih yang untuk pelaksanaan pemotongan hewan dan mendukung kegiatan pembersihan maupun desinfeksi. Setiap daerah harus mempunyai tempat pemotongan hewan yang harus memenuhi persyaratan teknis sesuai dengan yang ditetapkan oleh menteri pertanian. RPH/TPH didirikan untuk menyediakan daging yang Aman, Sehat, Utuh, dan Halal (ASUH) bagi masyarakat, beberapa persyaratan yang harus dipenuhi tempat 
pemotongan hewan adalah persyaratan teknis, meliputi fisik (bangunan dan peralatan), sumber daya manusia, dan prosedur teknis pelaksanaannya.

Kegiatan pemotongan hewan terdiri atas penerimaan dan penampungan, pemeriksaan ante-mortem, persiapan penyembelihan, penyembelihan, pengulitan, pengeluaran jeroan, pemeriksaan post-mortem, pembelahan karkas, pelayuan karkas, dan pengangkutan karkas. Kegiatan pemotongan hewan menghasilkan produk samping berupa air limbah. Air limbah adalah limbah organik biodegradable yang terdiri atas darah, sisasisa pencernaan, urin, dan pencemar lainnya yang dihasilkan dari proses pencucian (Budiyono et al., 2011). Padmono (2005) menambahkan bahwa air limbah sebagian besar dihasilkan dari air pembersihan ruang pemotongan, air pencucian saluran pencernaan, dan air pembersihan kandang hewan dengan beban pencemaran terbesar berasal dari darah.

Limbah pemotongan hewan yang tidak dikelola dengan baik berpotensi untuk mencemari lingkungan. Akinro et al. (2009) menyatakan bahwa produksi daging di RPH dapat menimbulkan masalah lingkungan apabila limbahnya tidak diolah dengan baik. Selain itu, limbah RPH yang tidak dikelola dengan baik dapat berdampak pada masyarakat yang bertempat tinggal di sekitar RPH. Menurut Singh et al. (2014), kegiatan RPH mempengaruhi kualitas air, tanah, dan udara di sekitarnya. Dampak ini dapat dirasakan oleh masyarakat yang bertempat tinggal dekat dengan RPH. Riset sebelumnya yang dilakukan oleh (Bello, 2008) menunjukkan bahwa $98 \%$ masyarakat yang bertempat tinggal dekat dengan RPH merasa terganggu dengan keberadaan RPH. Pembuangan limbah RPH di area terbuka dan badan air dapat mencemari lingkungan dan menimbulkan penyakit yang dampaknya dapat dirasakan oleh masyarakat yang bertempat tinggal di sekitar RPH. Berdasarkan Peraturan Menteri Lingkungan Hidup Republik Indonesia No. 2 tahun 2006, setiap penanggungjawab usaha dan/atau kegiatan RPH wajib melakukan pengolahan air limbah sehingga mutu air limbah yang dibuang atau dilepas ke lingkungan tidak melampaui baku mutu air limbah RPH.

Tempat pemotongan hewan (TPH) Amessangeng berlokasi di Kota Sengkang yaitu di Kelurahan Lamaddukelleng, Kecamatan Tempe, Kabupaten Wajo. Lokasi TPH Amessangeng sebelah utara berbatasan dengan sungai, sebelah timur berbatasan dengan pertamina amessangeng sebelah selatan dan barat berbatasan dengan pemukiman warga. Lokasi TPH Amessangeng yang berada di kawasan padat aktivitas dan telah lama berdiri namun belum ada tempat penampungan limbah yang tersedia disekitar TPH. Oleh karena 
itu, penulis ingin mengetahui kondisi penanganan limbah TPH Amessangeng, terkait langkah penanganan limbah yang telah dilaksanakan untuk mencegah terjadinya pencemaran lingkungan.

\section{METODE}

Penelitian dilaksanakan di Tempat Pemotongan Hewan (TPH) Amessangeng berlokasi di tengah Kota Sengkang yaitu di Kelurahan Lamaddukelleng, Kecamatan Tempe, Kabupaten Wajo. Metodologi penelitian yang digunakan adalah penelitian deskriptif kualitatif. Data yang digunakan adalah data primer dan sekunder. Data primer diperoleh secara langsung dengan cara pengamatan di lapangan dan wawancara informan. Data sekunder diperoleh dari berbagai macam sumber data lain yang relevan. Studi pustaka dilakukan dengan mencari landasan teori mengenai penanganan limbah TPH.

\section{HASIL DAN PEMBAHASAN}

Kegiatan pemotongan hewan di TPH Amessangeng menghasilkan limbah berupa darah, isi saluran pencernaan, dan sisa hasil pencucian lainnya. Limbah tersebut tercampur menjadi satu dibuang melalui saluran selokan. Limbah isi pencernaan dikelola supaya tidak menumpuk di saluran selokan dengan cara dibuang tidak secara bersamaan tetapi sedikit demi sedikit dan disertai dengan penyiraman air yang banyak sesuai dengan Gambar 1.

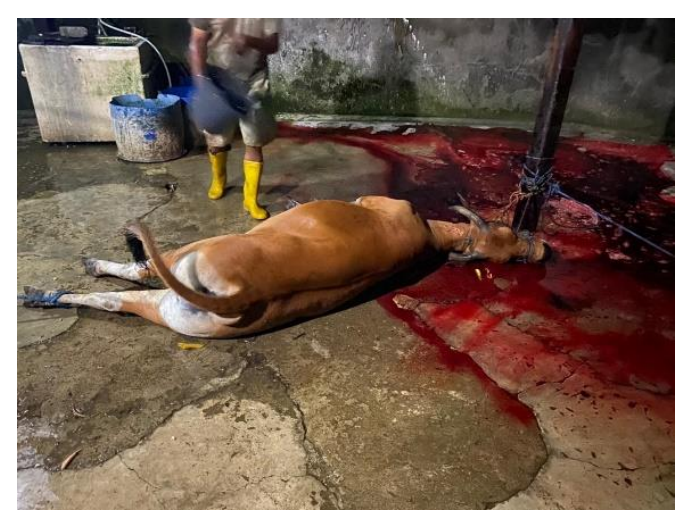

Gambar 1. Limbah pemotongan hewan

Saluran pembuangan TPH berfungsi dengan baik, sehingga limbah hasil pemotongan akan langsung mengalir keluar dari ruangan pemotongan hewan sesuai dengan Gambar 2. Setelah keluar dari ruangan pemotongan ukuran selokan menjadi lebih lebar, sehingga mampu mengalirkan limbah dan air lebih banyak dan mencegah terjadinya penumpukan limbah seperti pada Gambar 3. Menumpuknya limbah peternakan sampai dengan kapasitas tertentu akan menimbulkan dampak negatif antara lain berupa peningkatan populasi mikroba patogen sehingga mengakibatkan terjadinya pencemaran air, tanah dan pencemaran udara karena debu infeksius serta bau yang kurang sedap (Indrawati, 2017). 


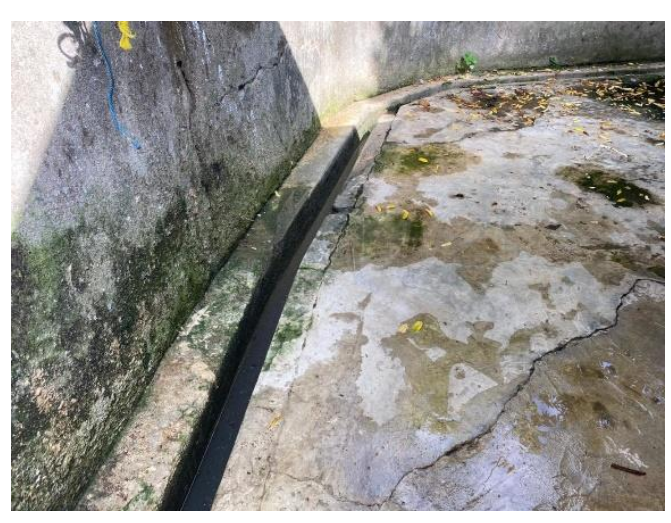

Gambar 2. Kondisi selokan dalam ruangan pemotongan hewan

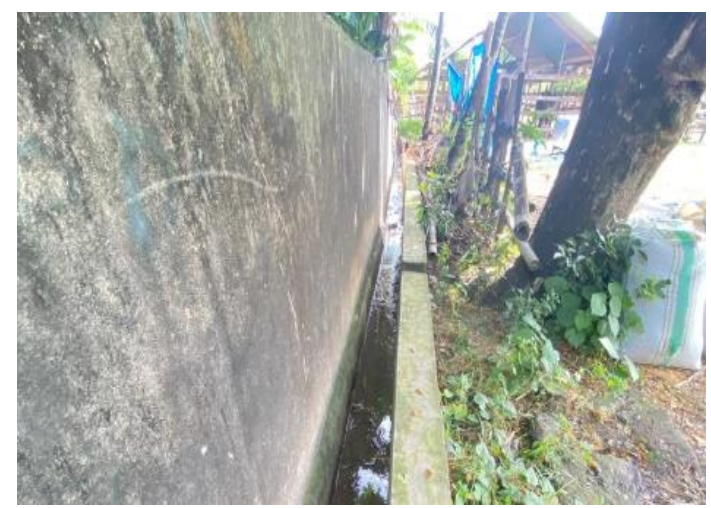

Gambar 3. Kondisi selokan di luar ruangan pemotongan hewan

Pembersihan limbah di ruangan pemotongan dilakukan dengan mengelontorkan air. Penggunaan air dapat mempercepat campuran limbah dan air menjadi lebih cair dan homogen sehingga mengalir lebih lancar di saluran selokan. Limbah yang mengalir di saluran selokan akan berujung di sungai yang berada di sebelah utara TPH.

Limbah yang dialirkan melalui saluran selokan terdiri dari campuran air, darah, isi saluran pencernaan dan sisa pencucian peralatan lainnya. Sebagian limbah isi saluran pencernaan yang melewati selokan, akan mengalami pengendapan jika pemotongan hewan sudah semakin banyak. Kondisi limbah yang mengalir melewati selokan berwarna coklat dan masih terlihat adanya sedikit padatan, namun selokan masih berfungsi dengan normal dan tidak terjadi pendangkalan, hal tersebut karena jumlah ternak yang dipotong masih dalam jumlah yang sedikit. Limbah hasil pemotongan ternak langsung dibuang ke sungai, tetapi belum dilakukan pengujian untuk mengetahui apakah kualitas limbah tersebut tidak mempengaruhi kondisi lingkungan/sungai yang berpotensi menimbulkan pencemaran baik pencemaran udara, air dan gangguan kesehatan.

Berdasarkan pengamatan kondisi penanganan limbah tempat pemotongan hewan (TPH) yang telah dilaksanakan, diketahui beberapa potensi yang dapat menimbulkan permasalahan. Kondisi yang ada memiliki potensi menjadi pencemaran lingkungan. Beberapa faktor penyebab terjadinya pencemaran tersebut antara lain:

1. Tidak ada kolam penampungan limbah yang disediakan TPH. Kolam penampungan limbah diharapkan mampu menampung limbah hasil pemotongan ternak. Semua air limbah dari ruangan pemotongan harusnya di alirkan ke kolam penampungan. Kolam penampungan ini diolah lebih lanjut 
dengan IPAL. Namun kolam penampungan limbah di TPH Amessangeng belum tersedia. Hal tersebut disebabkan karena jumlah pemotongan ternak masih sedikit, tetapi jika sudah dalam jumlah yang banyak maka kemungkinan besar akan menyebabkan dampak yang lebih buruk.

2. Limbah TPH langsung mengalir ke lahan dan berujung di sungai. Limbah yang dihasilkan TPH tidak dilakukan penyaringan terlebih dahulu dan langsung di buang dengan mengalirkan melalui selokan menuju ke sungai. Jika terjadi secara terus menerus dan dalam jumlah yang banyak maka kemungkinan terjadinya pengendapan limbah khususnya isi saluran pencernaan kemungkinan bisa terjadi, menimbulkan polusi bau, air akan tercemar dan gangguang kesehatan. Limbah cair yang dibuang ke lingkungan berpotensi membawa penyakit dan mencemari lingkungan di sepanjang daerah aliran air yang dilewati. Jangka panjang, hal tersebut dapat menimbulkan protes dari warga yang menandakan efek di lingkungan telah sampai pada kondisi buruk mengganggu aktivitas warga. Oleh karena itu, solusi penanganan limbah harus segera ditangani dengan tepat dengan memperhatikan berbagai faktor dari kondisi TPH Amessangeng, warga sekitar dan lingkungan.

TPH Amessangeng telah memiliki sarana dan prasarana yang memadai untuk pemotongan hewan, namun untuk pengelolaan limbah masih belum tersedia. Salah satu kendala yang dihadapi adalah belum adanya pengolahan limbah sebagaimana mestinya yang menyebabkan penanganan limbah tidak dilakukan sama sekali. Efek utama yang dapat ditimbulkan adalah pencemaran lingkungan berupa bau, sumber air tercemar dan berpotensi penyebaran penyakit. Secara umum permasalahan tersebut merupakan kendala umum bagi setiap tempat pemotongan hewan (TPH), terutama TPH yang jumlah pemotongan ternaknya masih dalam jumlah sedikit dan masih tradisional, perhatian terhadap pengolahan limbah juga masih sangat kurang. Berdasarkan pengamatan di TPH Amessangeng diperoleh alternatif solusi untuk mengatasi permasalahan limbah yang dihadapi.

Limbah dari hasil kegiatan pemotongan hewan dialirkan melalui selokan dan dilewatkan melalui sebuah saringan kasar yang berguna untuk menyaring kotoran seperti daun, bulu hewan dll. Tahap berikutnya adalah limbah dialirkan ke bak pemisah lemak atau minyak, bak tersebut berfungsi untuk memisahkan lemak atau minyak yang berasal dari kegiatan TPH, selain itu juga 
berfungsi untuk mengendapkan kotoran tanah, pasir atau padatan lain yang tidak diurai secara biologis. Tahap berikutnya adalah air yang telah mengendap kotorannya dialirkan ke bak ekualisasi yang berfungsi sebagai bak penampung limbah dan kontrol aliran, selanjutnya limbah dari bak ekualiasasi dipindahkan ke unit IPAL.

Pembangunan kolam penampungan harus dibangun untuk mengolah limbah lebih lanjut dengan instalasi pengolahan air limbah (IPAL). IPAL merupakan suatu perangkat peralatan teknik beserta perlengkapannya yang memproses / mengolah cairan sisa proses produksi pabrik, sehingga cairan tersebut layak dibuang ke lingkungan (Rahmawati, 2014). Persyaratan instalasi pengolahan air limbah (IPAL) adalah lokasi sebaiknya berada tidak terlalu jauh dari sumber/asal air limbahnya, tidak mengganggu lingkungan dari segi pandangan maupun dari segi kemungkinan bau, dan tidak jauh dari saluran pembuangan lingkungan. Posisi bangunan IPAL berada di atas tanah dan penghawaannya harus tidak mengganggu terhadap lingkungan (Kementerian Kesehatan, 2011).

Tempat pemotongan hewan menghasilkan limbah cair yang sebagian besar berasal dari darah, isi saluran pencernaan dan sisa pencucian/pembersih ruang potong dan peralatan lainnya. Kandungan limbah cair pemotongan hewan adalah bahan organik, padatan tersuspensi, serta bahan koloid seperti lemak, protein, dan selulosa dengan konsentrasi tinggi sehingga limbah cair pemotongan hewan termasuk ke dalam kategori limbah cair kompleks. Potensi bahaya yang ditimbulkan dari air limbah RPH yang diolah kurang sempurna atau tidak menggunakan instalasi pengolahan air limbah (IPAL) yaitu adanya bakteri-bakteri patogen penyebab penyakit, meningkatnya kandungan Biological Oxygen Demand (BOD), Chemical Oxygen Demand (COD), Total Suspended Solid (TSS), minyak dan lemak, pH dan NH3-N (Sari et al., 2018). Kementrian Lingkungan Hidup (2014) menambahkan bahwa baku mutu air limbah bagi usaha dan atau kegiatan $\mathrm{RPH}$ berdasarkan Peraturan Menteri Lingkungan Hidup No. 5 Tahun 2014 di antaranya limbah cair memiliki kadar paling tinggi untuk BOD 100 mg/l, COD 200 mg/l, TSS $100 \mathrm{mg} / \mathrm{l}$, minyak dan lemak 15mg/1, NH3N 25 mg/l dan pH 6- 9.

Limbah TPH Amessangeng langsung mengalir ke lahan yang berujung di sungai, limbah yang tidak diolah berdampak terhadap masyarakat sekitar yang meliputi polusi bau atau pencemaran udara, pencemaran air dan berdampak pada kesehatan. Pencemaran udara dapat terjadi karena campuran dua atau lebih bahan pencemar, baik padat, cair maupun gas yang terdispersi ke udara kemudian menyebar ke 
lingkungan sekitar. Bau yang dihasilkan dari suatu limbah dapat terjadi karena peristiwa oksidasi reduksi dari senyawasenyawa yang terkandung di dalamnya, serta dapat juga terjadi karena aktivitas mikrobia, baik dalam kondisi aerob maupun anaerob. Bau terjadi akibat lepasnya gasgas dari dalam air ke udara. Kondisi di sekitar TPH Amessangeng hampir tidak ada masyarakat yang merasa terganggu dengan bau yang ditimbulkan dari limbah TPH, hal tersebut disebabkan karena pengaruh sinar matahari yang bersinar sepanjang hari sehingga bekas limbah cepat mengering dan angin yang bertiup tidak ke arah pemukiman warga. Mawa'da (2012) menyatakan bahwa munculnya bau menyengat pada sekitar TPH disebabkan jika turun hujan ataupun angin kencang, tetapi gangguan bau tersebut akan menjadi bukan masalah ketika masyarakat sudah lama bermukim di sekitar TPH atau peternakan. Faktor lain yang menyebabkan tidak ada masyarakat yang merasa terganggu dengan limbah TPH adalah jumlah pemotongan hewan di TPH Amessangeng masih sedikit yaitu $2-4$ ekor per hari, sehingga limbah yang dihasilkan juga sedikit. Aini et al. (2017) menyatakan bahwa lokasi pemotongan hewan dengan jumlah pemotongan sapi 18-20 ekor per hari yang pengolahan limbah kurang maksimal menyebabkan warna air yang dihasilkan menjadi coklat dan munculnya bau amis sampai bau busuk di sekitar lokasi pemotongan hewan.

$$
\text { Pembuangan limbah TPH }
$$

Amessangeng yang berujung pada sungai disekitar TPH bisa mengakibatkan terjadinya pencemaran, yang merupakan masuknya mahluk hidup atau komponen lain ke dalam air yang menyebabkan kualitas air menjadi menurun dan tercemar. Kondisi umum pada TPH adalah limbah cair menjadi buangan yang bersifat rutin. Limbah cair pemotongan hewan bila dibuang di sungai mengakibatkan kualitas air menurun, yang disebabkan oleh kandungan sulfida dan amoniak bebas diatas kadar maksimum kriteria kualitas air. Selain itu Salmonella sp. yang membahayakan manusia (Nurfifi et al., 2017).

Keluhan kesehatan masyarakat yang berada di sekitar TPH Amessangeng hampir tidak ditemukan, hal tersebut disebabkan karena masyarakat tidak menjadikan air sungai sebagai sumber air untuk mandi, sehingga kemungkinan munculnya masalah pada gangguan kulit tidak terjadi. Umumnya kondisi masyarakat di sekitar TPH yang mengalami keluhan kesehatan adalah sesak napas yang biasa terjadi apabila konsentrasi bau yang tinggi muncul disekitar pemukiman, yang menyebabkan masyarakat susah untuk bernapas. Masyarakat yang berada disekitar TPH akan mencium bau berasal dari limbah urine 
dan darah, feses dan isi saluran pencernaan.

Selain itu kondisi kesehatan masyarakat juga dapat terganggu, disebabkan karena menggunakan air yang terkontaminasi dengan limbah TPH untuk mandi yang memungkinkan munculnya masalah gangguan pada kulit seperti gatal-gatal, hal tersebut dimungkinkan karena adanya zat kimia dari proses pengolahan limbah TPH. Keluhan kesehatan terjadi di masyarakat di sekitar lokasi pemotongan hewan diantaranya keluhan pernafasan seperti sesak nafas dan batuk serta keluhan penyakit kulit seperti gatal-gatal, bintikbintik merah, nyeri dan kulit bersisik (Nurfifi et al., 2017).

\section{KESIMPULAN DAN SARAN}

TPH Amessangeng telah memiliki sarana dan prasarana yang memadai untuk pemotongan hewan, namun berdasarkan hasil pengamatan menunjukkan bahwa kondisi pengolahan limbah belum tersedia. Pembuatan kolam penampungan limbah harus dilakukan dan dilanjutkan dengan pengolahan limbah menggunakan IPAL sebelum limbah dibuang ke sungai sekitar TPH untuk mencegah munculnya polusi udara, polusi air, tanah dan gangguan kesehatan.

\section{DAFTAR PUSTAKA}

Aini, A., Sriasih, M., \& Kisworo, D. (2017). Studi Pendahuluan Cemaran Air Limbah Rumah Potong Hewan di Kota Mataram. Jurnal Ilmu Lingkungan. 15(1), https://doi.org/10.14710/jil.15.1.42-48

Bello W B. (2008). Problems and Prospect of Organic Farming in Developing Countries. Ethiopian Journal of Environmental Studies and Management., 1, 36-43.

Budiyono, Widiasa, I. N., Johari, S., \& Sunarso. (2011). Study on Slaughterhouse Wastes Potency and Characteristic for Biogas Production. International Journal of Waste Resources, 01(2), 4-7. https://doi.org/10.4172/22525211.1000102

Indrawati, R. (2017). Penurunan BOD Pada Biogas Kotoran Sapi Campuran Limbah Cair Industri Penyamakan Kulit Dengan Variasi Kecepatan Dan Lama Pengadukan. Journal of Research and Technology, 3(2), 4453.

Kementerian Kesehatan. (2011). Instalasi Pengolahan Air Limbah. Direktorat Bina Pelayanan Penunjang Medik Dan Sarana Kesehatan, Jakarta, 4-5.

Kementrian Lingkungan Hidup 2014. (2000). Peraturan Menteri Lingkungan Hidup No. 5 Tahun 2014 Tentang Baku Mutu Air Limbah. Political Science, 52(2), 174-180. https://doi.org/10.1177/00323187000 5200207

Khasrad, Hellyward, J., \& Yuni, A. D. (2012). Kondisi Tempat Pemotongan Hewan Bandar Buat Sebagai Penyangga Rumah Pemotongan Hewan (Rph) Kota Padang. Jurnal Peternakan Indonesia, 14(2), 373378.

Nurfifi, S., Jafriati, \& Ardiansyah, R. T. (2017). Analisis Pengelolaan Limbah UPTD Rumah Pemotongan Hewan (RPH) Dan Dampaknya Terhadap 
Masyarakat Sekitar Kelurahan

Anggoeya Kecamatan Poasia Kota Kendari. J Kesimkesmas Jurnal Ilmiah

Mahasiswaehatan Masyarakat, 2(6), $1-10$.

Padmono, D. (2005). Alternatif Pengolahan Limbah Rumah Potong Hewan Cakung ( Suatu Studi Kasus ). J. Tek. Ling. P3TL. BPPT, 6(1), 303-310.

Sari, E. D. A., Moelyaningrum, A. D., \& Ningrum, P. T. (2018). Kandungan Limbah Cair Berdasarkan Parameter Kimia di Inlet dan Outlet Rumah Pemotongan Hewan ( Studi di Rumah Pemotongan Hewan X Kabupaten Jember). Journal of Health Science and Prevention, 2(2), 88-94.

Singh, S., Moholkar, V. S., \& Goyal, A. (2014). Optimization of carboxymethylcellulase production from Bacillus amyloliquefaciens SS35. 3 Biotech, 4(4), 411-424. https://doi.org/10.1007/s13205-0130169-6. 